\title{
Interrogating the Criminalisation of Same-Sex Sexual Activity: A Study of Commonwealth Africa
}

\author{
Augustine Edobor Arimoro ${ }^{1,2}$ [D
}

Accepted: 8 April 2021 / Published online: 27 April 2021

(c) The Author(s) 2021

\begin{abstract}
The Abrahamic faiths and received colonial law have been identified as the driving force behind the criminalisation of homosexual activity in most of the Commonwealth States of Africa. This article, therefore, seeks to question the role of criminal law in proscribing sexual activities amongst consenting adults of the same gender in Commonwealth African states. A recurring question in the paper is the propriety of criminalising a consensual conduct amongst consenting adults in private when no harm or injury is done to other citizens or the state in line with JS Mill's principle of harm. The article finds that the misconception that the main aim of criminal law is to legislate the moral values of the majority, forms support for the view that homosexuality can be learned and unlearned and if this is the case, a paternalistic approach by the state would help mould citizens' behaviour. A comparative and case study approach was adopted for the discussion in the article. Four Commonwealth African states, namely, Ghana, Kenya, Nigeria and Uganda were selected as case studies. The article recommends a much more robust approach for the support of sexual minorities in the Commonwealth.
\end{abstract}

Keywords Homosexuality $\cdot$ Commonwealth $\cdot$ British colonies $\cdot$ Same-sex sexual conduct

\section{Introduction}

The criminalisation of same-sex sexual conduct in most Commonwealth States is traceable to colonial laws received from Britain. Britain, where colonial anti-sodomy laws were imported from, repealed her anti-sodomy laws in 1967 following the Wolfenden Commission Report. Interestingly, the Commonwealth accounts for

Augustine Edobor Arimoro

augustine.arimoro@ntu.ac.uk

1 Nottingham Law School, Nottingham Trent University, Nottingham, United Kingdom

2 Centre for Comparative Law in Africa, UCT, Cape Town, South Africa 
$30 \%$ of the world population (Gerber 2014). Furthermore, 'approximately four out of every five countries that make up the Commonwealth continue to criminalise homosexuality' (Gerber 2014: 78). In 2018, the former British Prime Minister, Mrs Theresa May, was reported to have regretted the role Britain played in criminalising same-sex relations in its former colonies (British Broadcasting Corporation 2018). Several years after independence, these Commonwealth States have maintained their anti-gay laws. This article aims to, among others, scrutinise the rationale for the continued criminalisation of consensual sexual activity amongst adults of the same gender in majority of the Commonwealth States. Given that Africa has the largest number of Member States that criminalise homosexuality within the community (Gerber 2014), ${ }^{1}$ four African Commonwealth Members States have been selected for this study. These include Ghana, Kenya, Nigeria and Uganda.

What constitutes criminal behaviour varies from one country to another (Monaghan 2018). For example, same-sex sexual activity amongst two adults in private is a criminal offence in Saudi Arabia but it is not criminalised in the United States. Similarly, what may be a crime in one era may be decriminalised in another (Monaghan 2018). For example, suicide was a crime in England and Wales up until 1961. ${ }^{2}$ In the same vein, in England, the rape of a woman by her husband was previously not considered as an offence. This is no longer the position as the House of Lords in $R v R$ (Rape: Marital Exemption) ${ }^{3}$ recognised that a husband could rape his wife and thus, the act would constitute a crime. Following from the above, a crime may be regarded as:

...conduct which the law deems to be criminal under statute (an Act of Parliament) or common law (case law). Such a conduct is prohibited because it involves the threatening or causing of harm to individuals or to public interests. Conduct may be deemed to be criminal due to moral and/or social reasons (Monaghan 2018: 3).

This article argues that the criminalisation of homosexuality in Commonwealth Africa is largely due to colonial ties with Britain as well as the influence of the Abrahamic faiths, that is, Christianity and Islam (Ireland 2013). Also, the article posits that the decriminalisation of homosexuality is challenged by the politics of religion on the continent. Following from the above, this article submits that the law of crime should focus more on protecting society from harm. The article begins with a definition of crime and discusses what the state should consider in formulating laws criminalising certain acts or omissions. The article is divided into two sections. The first section discusses criminallaw priniciples whilst the second examines the criminalisation of homosexual activity in some selected Commonwealth African States. It remains to be stated that the focus of this article is on crime and not on the rights of sexual minorities. As such, the criminalisation of consensual sexual conduct among consenting adults in private is examined.

\footnotetext{
1 At least 16 Commonwealth States in Africa criminalise homosexuality.

2 Suicide as a crime was abolished vide the Suicide Act 1961 in England and Wales.

3 [1992] 1 AC 599.
} 


\section{What is a Crime?}

The question 'What is a crime?' is one which attracts different answers, and which has evolved over the years (Michalowski 2016). A crime is considered as 'an offence against the state, as well as against individuals and is a public wrong' (Loveless et al. 2020: 3). Although a crime may be committed against individuals, a crime is a wrong that attracts sanction(s) from the state. Hermalin points out that not all wrongs are criminal (Hermalin 2005). What makes an act or an omission a crime lies in the simple fact that society declares it a crime and penalises anyone who commits the act or omission. For example, if Mr A steals Mr Y's book worth $£ 100$, that is a wrong which is labelled as a crime. However, if Mr A causes damage worth $£ 1000$ to Mr Y's car as a result of an accident, this is a wrong but cannot be treated as a crime. As Hermalin further notes, a breach of a contract which costs the plaintiff a lot of damage, although a wrong on the part of the defendant, is a wrong but is not treated as a crime (Hermalin 2005). Thus, what constitutes a crime is always not a result of the quantum of the damage caused. The question that now follows is this: which wrongdoings should be considered criminal? In response to this question, Spencer and Mohr state as follows:

Crime in modern societies can be defined officially as acts or omissions prohibited by law and punishable by sanctions. Although crime is sometimes viewed as the equivalent of antisocial, immoral and sinful behaviour or as a violation of any important group standard, no act is legally a crime unless prohibited by law (Spencer and Mohr 2019: para 3).

Spencer and Mohr's definition of crime above is deficient to a certain extent. Their definition does not differentiate between acts or omissions that are prohibited by law, but which are not punishable by the state. To say that an act or omission is punishable by sanctions does not necessarily mean that it is a crime. For instance, a civil wrong ${ }^{4}$ committed by one person against another could attract sanctions but that does not make the wrong a crime. To properly define what action or omission constitutes a crime, there is need to take into cognisance the fact that such a wrong is usually prosecuted by the state (although it is possible to have private prosecution) (Legal Services Commission 2020). To clarify this point, the following illustration may be helpful. A person who takes money without the permission of the owner commits a crime whereas if the same person borrows the money and fails to pay back, the person commits a civil wrong. It may also happen that the borrower could be prosecuted for a criminal offence if the borrower obtained the loan via fraud. Thus, for the purpose of this article, a crime is any act or omission which breaches societal rules and for which the state will apply sanctions (Case et al. 2017).

Following the definition of crime above, there is the need to consider what behaviour a state may label and punish as a crime. Should the law of crime of a state be based on morality, religious doctrines or on what society considers abnormal

\footnotetext{
$\overline{4}$ A civil wrong (tort) may lead to an action that requires compensation or restitution.
} 
behaviour? Furthermore, to what extent might the state seek to maintain 'accepted standards' for the society? For example, politicians in Nigeria claim that homosexuality is 'uncultural' and as such should be considered criminal conduct (Arimoro 2018). The vexed question now arises, what act or omission should be labelled as a crime in an evolving world? To answer this question, this article considers some theories of crime.

\section{Priniciples of Crime: Harm, Moralism, Paternalism and Religion}

Without an understanding of why a conduct is criminalised, criminal law might become a tool for denying human liberty and freedom (Arimoro 2020). There is a need to question the reason why certain forms of behaviour are considered a crime and punished accordingly (Loveless et al. 2020). In this section, harm, morality, paternalism, and religion are examined as the basis for which states may criminalise certain behaviour. The aim is to interrogate the continued criminalisation of homosexual conduct amongst consenting adults in private in most Commonwealth African States.

\section{Harm}

The harm priniciple posits that to justify punishment, a crime should protect citizens from 'harm' (Loveless et al. 2020). Proponents of the harm theory argue that only harm provides a 'suitably non-partisan base for justifiable legal interference' (Kleinig 1978: 27). What this means is that for the state to identify any behaviour or conduct as criminal, the behaviour or conduct in question must be considered as harmful to other citizens. Hence, the harm is a violation of a legally protected interest (Eser 1966).

The 'harm principle' is largely credited to the seminal work of JS Mills. The principle is founded on liberal values and one can argue that the doctrine is instituted on the premise that individuals can do what they wish, so long as their acts or omissions do not harm others. Mill's thesis on 'harm' has contributed significantly to debates regarding the limits of legitimate state/social action (Saunders 2013). Mill argued that the 'only purpose for which power can be rightfully exercised over any member of a civilised community, against his will, is to prevent harm to others' (Mill 2008). In essence, the state must keep society functional and civil. According to Mills, the behaviour of a citizen in a state should only be limited to prevent a situation where harm is caused to other citizens. It has been noted that the infliction of harm upon another person is what makes a behaviour (in this case, action or omission) wrong (Oliveira 2012). Again, it is considered that what should be labelled as a criminal behaviour should be an activity that infringes on 'the rights of others through force 
or fraud, or the deliberate actions that place others involuntarily at significant risk of harm.' 5

Following from the above, if an individual's behaviour does not harm another citizen, why then should that conduct be criminalised? The harm principle has 'served as a justification for the decriminalisation of sexual conduct of sexual minorities' (Stewart 2010:18). Again, the harm principle has justified the creation of new offences as it has become clear that some behaviour could give rise to societal harm which was not so considered in times past. For example, the ban on smoking in enclosed public places in the UK, giving that smoking poses a health risk to other citizens and not only to the person that is smoking.

On his part, Feinberg states that the only two considerations that a liberal state should take into cognisance when deciding on what behaviour should be criminalised are:

1. The Harm Principle: It is a justifiable reason for penal legislation to prevent harm to persons other than the actor, that is, the one prohibited from acting.

2. The Offence principle: It is a justifiable reason in support of proposed criminal prohibition that is necessary to prevent serious offence to persons other than the actor (Feinberg 1987).

Here, Feinberg elaborates on the libertarian harm principle. He further links the harm principle with rights and argues that '...no plausibly interpreted harm principle could support the prohibition of actions that cause harms without violating right...' (Feinberg 1987: 36). In the light of the above, it may well be said that while the law should protect cultural values, human rights are sacrosanct and must not be violated in the preservation of cultural values (Arimoro 2018). Criminal law must protect human rights and not infringe on them.

Harm must be serious and must be a threat to other citizens or society. Thus, the laws of crime that protect the autonomy of the person, and ensures the preservation of order should be the focus of the state. As such, criminal law should focus on conducts which are harmful to society. The harm principle is not without criticisms (Dripps 2010), chief of which is that the principle limits the law of crime to only harmful conduct to other citizens. As a result, it confines criminal law. The libertarian approach of harm may prevent the state from acting on what is in the best interest of the state. This article argues that where the state seeks to criminalise behaviour that is not in the best interest of the society and of course where there is no direct harm to others, the rights of the 'perpetrator(s)' of that conduct must not be infringed upon merely to uphold societal interests as human rights are sacrosanct. Having discussed harm, this article considers moralism next.

\footnotetext{
5 This quote is from the United States Libertarian Party platform which has adopted a version of the harm principle.
} 


\section{Moralism}

For this discussion, a good question, to begin with, is this: should the law of crimes in a state control individual morality? While there is no universally accepted definition for morality or moralism, for the purpose of this work, defining the concept(s) is crucial for the sake of clarity. Philosophers often link the concept of morality with ethics (Embley et al. 2020). Moral principles are ethical duties on the part of individuals. Moral principles form part of the common law. For example, judges and lawyers in common law jurisdictions often refer to 'natural justice', a term which reflects moralism. Another example is the introduction of the 'Love thy Neighbour' principle into English law. In the celebrated case of Donoghue $v$ Stevenson, ${ }^{6}$ Lord Atkin adopted the principle of being good to neighbours to formulate the "neighbour principle', which today underpins the modern law of negligence. ${ }^{7}$

It is not all moral duties that are legally enforceable. Again, should the courts retain a residual power to enforce moral codes through criminal law? It does appear, and rightly so, that moralism or morality is at the opposite end of the harm principle discussed above. It has been argued that 'moralism, therefore, challenges the limitations of the harm principle' (Loveless et al. 2020: 5). It is not uncommon to find jurisdictions where moral rules have the backing of the law and where such rules are breached, they are met with sanctions. For example, while adultery is not a crime in the UK, it is an offence in some other jurisdictions, such as Pakistan and Saudi Arabia (Embley et al. 2020).

UK courts have sometimes adopted a moralistic approach in applying the law. For example, conspiracy to corrupt public morals and conspiracy to outrage public decency were judicially created offences in the 1970s to criminalise and censure publications concerning prostitution in Shaw $v$ DPP. ${ }^{8}$ The case of Knuller $v$ $D P P^{9}$ provides another example of the influence of morality on criminal law as the court criminalised homosexuality at a time when it was not an offence known to law (Loveless et al. 2020).

Notably, the Wolfenden Committee Report on Prostitution and Homosexual Offences 1957 reviewed both the Shaw and Knuller cases and 'took the view that criminal law had no role in the enforcement of morality' (Loveless et al. 2020). The Committee recommended, among other things, that homosexuality should be decriminalised (McCutcheon 2002-2003). The liberal views of the Committee were criticised by the leading jurist, Lord Devlin, who thought that the law 'should rightly enforce moral principles and nothing else' (Loveless et al. 2020: 5). With respect, Lord Devlin's opinion is an unnecessary and onerous burden that the state should not be made to bear. This approach will mean that it will become a crime not to live like a 'Good Samaritan'. Also, would the state have the resources to enforce all 'good' standards of behaviour?

\footnotetext{
${ }^{6}$ [1932] AC 562.

7 Supra.

8 [1962] HL AC 220.

9 [1973] AC 435.
} 
Morality, therefore, concerns the distinction between right and wrong or good and bad behaviour and the urge for individuals to do that which is good or right. If the state is mainly concerned about right or wrong and not mindful of how criminal law affects the rights of the citizens to live their own private lives, it would lead to a situation a situation where the prevalent state-sponsored violation of human rights cannot be avoided.

\section{Paternalism}

Paternalism is considered to be the main reason why the state may intrude into a private adult's life. This is specially to protect a vulnerable victim from abuse or exploitation. In this sense, criminal law assumes a moral approach (Tur 1985). This is in contradistinction to the harm or offence principle that determines what conduct is labelled a crime based on a liberal approach (Kleinig 2016). There are diverse meanings of what the concept 'paternalism' refers to. One of these is a suggestion that it refers to the state knowing what is in the best interest of the individual citizen better than the individual citizen know of their self (Feinberg 1989).

The English courts have established the concept of 'public interest' to cement paternalism within the fabric of English criminal law. In $R v$ Brown, ${ }^{10}$ the appellants on their own accord participated in acts of violence against one another as they engaged in private homosexual sadomasochistic encounters for the sexual pleasure derived in giving and receiving pain. The convictions were confirmed by both the Court of Appeal and the House of Lords. In his dissenting opinion (for the minority), Lord Mustill stated as follows:

My Lords, this is a case about the criminal law of violence. In my opinion it should be a case about the criminal law of private sexual relations, if about anything at all...I must confess that this distribution of the charges against the appellants at once sounds a note of warning... ${ }^{11}$

The majority decision in Brown was also adopted in the unreported case of $R$ $v$ Emmett (Loveless et al. 2020). ${ }^{12}$ In this case, as part of consensual heterosexual activity, a woman agreed to have a plastic bag tied over her head and the lighting of a fire on her breast which caused a burn that got infected. Her partner was convicted of a charge of occasioning actual bodily harm. It thus follows that the court in Brown did not frown at the homosexual activity amongst consenting adults in private, but against the violence that the defendants unleashed on one another. The paternalistic approach of the court here is to prevent violence in the public interest.

Thus, where the state wishes to act in the 'public interest' as far as conduct between consenting adults in private is concerned, the objective is to prevent acts of violence. To this end, the development of the law in England is quite commendable

\footnotetext{
${ }^{10}$ [1994] 1 AC 212.

11 Supra 556.

12 [1999] See the Independent 19 July 1999.
} 
and should provide a template for Commonwealth Member States. This is so because the anti-sodomy laws in Commonwealth Member States have their origin in received colonial laws from Britain. As such, homosexuality that involves acts of violence should be criminalised and this should in no way apply to consensual sexual activity amongst adults in private.

\section{Religion}

There is no gainsaying the fact that religion plays a major role in the way of life of most citizens in Commonwealth Member States in Africa (Arimoro 2018). Religion influences the public discourse on sexuality in general and on views regarding homosexuality. It is indeed trite that Africans are notoriously religious. For example, the four states that have been selected for this study are known for the influence that religion plays in their national lives (Arimoro 2018).

There is no universally accepted definition of the term 'religion.' It is noteworthy however that religion has been identified with beliefs in mysteries (Liquin et al. 2020). Religious beliefs evoke concepts about the eternal afterlife, immortal battles of good versus evil as well as a devotion to that which is considered divine (Moon et al. 2019). Religious beliefs are known to 'involve both mundane aspects of everyday human behaviour and those seeming baser activities, such as sexual behaviour' (Moon et al. 2019: 361). This aspect of religion contributes to the reason why most African Commonwealth States continue to criminalise homosexuality. The main religions in Commonwealth African States include the Abrahamic faiths (Christianity and Islam) and African traditional beliefs (Okeke et al. 2017). With the eroding influence of African traditional religions, the Abrahamic faiths largely dominate the way of life and influence the law-making process in the majority of Africa (Agbiji and Swart 2015).

In support of the continued criminalisation of homosexuality even among consenting adults in private, Christians refer to seven Biblical passages (Gnuse 2015). The passages include the following: Noah and Ham (Genesis 9:20-27), Sodom and Gomorrah (Genesis 19:1-11), Levitical laws condemning same-sex relationships (Leviticus 18:22), two words in two Second Testament (1 Corinthians 6:9-10; 1 Timothy 1:10), and Paul's letter to the Romans (Romans 1:26-27). Gnuse argues that the reference to homosexuality in the Bible was not about sexual relationships between two consenting adults in private (Gnuse 2015). He states that what the Bible condemns is homosexual rape as in Lot's story in the Bible as well as cultic homosexuality, which view is similar to that of the English courts with regards to homosexual sadomasochism. ${ }^{13}$

The Qur'an, which is the holy book of the Muslims, mentions sex between men several times, most of which are in the context of the (Lut) Lot and Sodom and Gomorrah story (like what is contained in the Bible) (The Global Alliance for

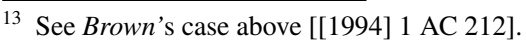


LGBT Education 2020). Scholars have referred to the following (Qur'anic) Islamic verses as the basis for the prohibition of homosexual behaviour:

And Lut said to his people: Will you commit a horror that none of the world's inhabitants have committed for you? - Sura 7:80-81

You approach men with lust instead of women. No, you are a people who go beyond the limits. - Sura 7:81-82

And we (Allah) let rainfall on them. Look how that was the end of the wrong doers. - Sura 7:84

He (Lut) said, "Really, I despise your conduct." - Sura 26:169

Do you lustfully approach men instead of women? No, you are ignorant people.

- Sura 27:56

The verses above are some of the verses that support Islam's prohibition of sex between men. Although there is no direct mention of lesbian sex in the Qur'an, some scholars consider it to be the same as Zina (which is punishable as sex outside of marriage) (The Global Alliance for LGBT Education 2020).

The politics of religion in Africa is largely the reason why Islam and Christianity shape the political and democratic landscape (Salau 2020). It is, therefore, difficult to foresee a situation where lawmakers will accept a change of the law as far as the criminalisation of homosexual behaviour is concerned. This is because politicians fear that they will lose the support of the electorate if they decide against the wishes of the people (Omelicheva 2018). As a result, the rights of sexual minorities in those states continue to be sacrificed on the altar of religious beliefs. Ironically, the selected states for this study, namely, Ghana, Kenya, Nigeria and Uganda hold out to be secular states. The Constitutions of the States provide as follows:

The State shall actively promote the integration of the peoples of Ghana and prohibit discrimination and prejudice on the grounds of place of origin, circumstances of birth, ethnic origin, gender or religion, creed or other beliefs. - Article 35(5) Constitution of Ghana 1992

There shall be no State religion. - Section 8 Constitution of Kenya 2010

The Government of the Federation or of a State shall not adopt any religion as State Religion. - Section 10 Constitution of Nigeria 1999 (as amended)

Uganda shall not adopt a State religion - Section 7 Constitution of Uganda 1995

It is clear from the above, that the framers of the Constitutions of these states have entrenched that the adoption of a state religion is unconstitutional. It should follow as well that given the secular nature of these states, religion should not form the basis of the criminalisation of an act or omission especially if the prohibition of the act or omission violates the fundamental rights of citizens even if they happen to be a minority. 


\section{Ghana, Kenya, Nigeria and Uganda}

In this section of the article, the criminalisation of same-sex sexual relations in four selected Commonwealth Member States is comparatively examined. The selected Commonwealth States in focus include Ghana, Kenya, Nigeria and Uganda. Although this article focuses on the criminalisation of behaviour, reference is made to the works of scholars who have discussed homosexuality as a fundamental right. Furthermore, while it is acknowledged that there have been rare convictions for sodomy in these States, it should be noted that anti-sodomy laws promote homophobia (Oloka-Onyango 2015). This often leads to harassment and intimidation of the lesbian, gay, bisexual and transsexual (LGBT) community by security forces and citizens as well. The argument that same-sex sexual conduct is 'uncultural' or 'unAfrican', even without even without credible scientific evidence, seems to suggest that homosexuality was a crime in traditional African societies (Arimoro 2018). This aligns with the view that British colonial laws and the Abrahamic faiths are the main reasons for the continued criminalisation of homosexuality in most Commonwealth African States. The countries for this study have been selected due to their leadership role in Africa and for their stance on the criminalisation of homosexual conduct.

\section{The Criminalisation of Homosexual Behaviour in Ghana}

In Ghana, homosexuality is not viewed as a human rights issue (Gyasi-Gyamerah et al. 2019). Furthermore, homosexual behaviour is considered as a 'form of social cancer that the entire society must vigorously combat' (Gyasi-Gyamerah et al. 2019). In March 2020, Dr Hanna Lusia Bisiw, who is the National Women's Organiser of the National Democratic Party, ${ }^{14}$ in response to news of a possible Pan Africa International Lesbian and Gay Association (ILGA) 5th regional conference, stated that homosexuals should be killed. She is quoted as follows:

Homosexuality is a disease. In veterinary you don't have to condone homosexuality; you have to kill animals that attempt same-sex mating. Why should humans do that? (Human Dignity Trust 2020).

In February 2020, Sheik Muumin Abdul Harou, who is the chief Imam of the Ashanti region stated regarding the same conference:

Wallahi tallahi [I swear to God] we will not agree; we Muslims, Christians and the traditional religion will all rise up. We will not allow them to even step foot here and not even the government can stand in our way. The country does not belong to them; it belongs to us so we decide who does what here...homosexuality is evil that must not be countenanced in any way because it is despised by God...Allah does not permit that in any way and our Prophet Mohammed

$\overline{14}$ The main opposition party in Ghana. 
said that if we see people who practice that behaviour, we should arrest them and kill them (Human Dignity Trust 2020: para 11-12).

Apart from religious leaders in Ghana who take a hostile view towards homosexuality, it is argued that the medical community in the country share the same bias (Norman et al. 2016). As a result of this, there are serious concerns regarding the health and treatment of gay persons in Ghana (Norman et al. 2016).

In 2007, the Deputy Attorney General of Ghana was reported to have claimed that homosexuality remains a crime under the country's statutes (Refugee Review Tribunal 2007). The report continues:

He explained that charters and international conventions that recognise homosexualism (sic) do not override national laws. For that reason, the Criminal Code of 1960, which outlaws homosexualism (sic) is incontrovertible, says the Dep. AG. He was speaking in an interview with the media at the ongoing 41st Ordinary Session of the African Charter on Human and People's Rights (ACHPR), where gay right activists accused the organisers of ailing to put their rights on the table for discussion.

Hon. Prempeh said unnatural carnal knowledge is an illegal act under the Criminal Code as per section 104, and homosexualism (sic), without any equivocation, is a form of unnatural carnal knowledge (Refugee Review Tribunal 2007).

However, it is noteworthy that there is no specific Ghana legislation that explicitly criminalises homosexuality (Refugee Review Tribunal 2007). Nevertheless, the prosecution of homosexual activity in Ghana can be initiated under the relevant section of the Ghana Criminal Code 1960. Section 104 of the Ghana Criminal Code 1960 distinguishes between non-consensual and consensual sexual intercourse in an' unnatural manner'. While non-consensual unnatural carnal knowledge is a firstdegree felony, consensual unnatural carnal knowledge is a misdemeanour. ${ }^{15} \mathrm{Sec}-$ tion 104 of the Ghana Criminal Code, last amended in 2003, states:

1. Whoever has unnatural carnal knowledge-

a. of any person of the age of sixteen years or over without his consent shall be guilty of a first degree felony and shall be liable on conviction to imprisonment for a term of not less than five years and not more than twenty-five years; or

b. of any person of sixteen years or over with his consent is guilty of a misdemeanour; or

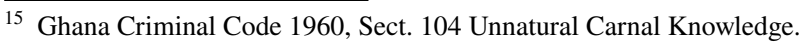


c. of any animal is guilty of a misdemeanour.

2. Unnatural carnal knowledge is sexual intercourse with a person in an unnatural manner or with an animal.

Although the interpretation of the above provision of Ghana's Criminal Code is ambiguous, it lays the foundation for the prosecution as well as discrimination against homosexuals in the country. ${ }^{16}$ Ghana's Criminal Code was inspired by colonial laws derived from Britain (Atuguba 2019). It is noteworthy that under Ghana criminal law, to establish carnal knowledge, the prosecution must prove that there was 'penetration'. Thus, it appears that in Ghana the prosecution may not be able to prove carnal knowledge where the act involves two or more women engaged in lesbian act (Atuguba 2019).

The use of the term 'unnatural carnal knowledge' to cover homosexuality in Ghanaian criminal law leaves a lot of room for uncertainty. This is because even two adults engaging in heterogenous sexual activity may be also charged with the same offence. For example, it will be a crime in Ghana if a man penetrates the anus (sodomy) or mouth (felatio) of a female with his penis. One can say that the only mode of sexual intercourse that is not illegal in Ghana is sex per vaginam, that is, sexual intercourse through the vagina by penile penetration (Atuguba 2019). Indeed, it has been argued, and rightly so, that the ambiguity posed by section 104 of the Ghana Criminal Code does not only criminalise homosexual conduct but also sexual activities that heterosexual couples may engage in Atuguba (2019).

From the above, it follows that morality or religion and received British colonial laws remain the reason behind the criminalisation of sexual relations among adults of the same gender in Ghana. The question remains, should Ghana a secular state, criminalise consensual sexual relations among adults in private? Presently, the Ghanaian state appears to adopt a moralist approach as far as that country's antisodomy law is concerned. The notion by religious leaders and politicians in Ghana that homosexual behaviour is a 'social cancer' portray the criminalisation of behaviour based on religious doctrines. This is contrary to the spirit of the constitution of Ghana which declares the country a secular state. There should thus, be a separation between religion and the state. In line with the harm theory, where an act or omission does not harm others, especially a private conduct among consenting adults, such an act or omission should not be criminalised.

\section{The Criminalisation of Homosexual Behaviour in Kenya}

Most Kenyans hold the view that homosexuality is foreign and an importation from the West (Finerty 2012). However, Mutua has argued that this perception, although deeply rooted in the minds of Kenyans, is the direct opposite of the fact as homophobia is not 'homegrown' but traceable to the country's colonial past (Mutua 2011).

\footnotetext{
16 The authorities in Ghana have on several occasions confirmed that the provisions of the Criminal Code criminalise homosexual behaviour.
} 
This supports the view that there were homosexuals in precolonial Africa and that they were not sanctioned for their sexual behaviour (Arimoro 2019).

The Catholic Church in Kenya is officially opposed to any form of sexual relationship that is outside the context of marriage (Mbote et al. 2018). The Church is also opposed to same-sex relationships (Mbote et al. 2018). The same view is shared by the Protestant Church in Kenya (Mbote et al. 2018). Muslims in the country oppose homosexuality based on the provisions of the Qur' an mentioned earlier and on some Islamic Hadiths. ${ }^{17}$ The Hadiths call for the execution by stoning of anyone who engages in same-sex sexual activity. ${ }^{18}$

Homosexuality is criminalised in Kenya under the country's Penal Code. Sections 162, 163 and 165 of the Kenya Penal Code are on all fours with section 377 of the Indian Penal Code, which provided a template for anti-sodomy laws that were introduced by the British to their colonies during the 1890s. Section 162 of the Penal Code provides thus:

Any person who has carnal knowledge of any person against the order of nature or permits a male person to have carnal knowledge of him or her against the order of nature is guilty of a felony and is liable to imprisonment for fourteen years.

Section 163 of the Kenya Penal Code provides that any person who attempts to commit any of the offences in section 162 is guilty of a felony and is liable to imprisonment for seven years. ${ }^{19}$ Furthermore, section 165 of the Code outlaws committing, encouraging or attempting 'acts of gross indecency' between males and imposes a penalty of up to five years jail term. ${ }^{20}$ It is considered that these provisions implicitly criminalise homosexual behaviour in Kenya even where it involves two consenting adults in private. Again, like Ghana, the Kenyan law that proscribes homosexual behaviour is not explicit. Carnal knowledge against the order of nature so defined is construed to include anal and oral sex and, in some cases, other 'non-procreative acts such as mutual masturbation' (Misra 2009). Even though heterosexual couples also do partake in these acts, the focus is always on homosexual sex when these provisions are read (Misra 2009). There are records of successful prosecution and conviction of persons accused of homosexual conduct in Kenya. In Francis Odingi $v$ Republic, ${ }^{21}$ FO was accused in 2006 of alleged homosexual conduct, convicted and sentenced to six months imprisonment. ${ }^{22}$ Also, the Court of Appeal in Kenya upheld the conviction of the accused in Julius Waweru Pleuster v Republic. ${ }^{23}$

There was an attempt by the Kenyan Parliament in 2014 to enact anti-homosexual legislation with harsher and stricter penalties for same-sex sexual activity modelled

\footnotetext{
17 The Hadiths are reports which describe the deeds, approvals and tacit approvals of Prophet Muham$\operatorname{mad}(\mathrm{SAW})$.

18 Abu Dawud 38:4448, Al-Muwatta 4141.111 and Tirmidhi 1:152.

19 See sections 162 and 163 of the Kenya Penal Code.

20 Section 165 Kenya Penal Code.

21 (2011) eKLR.

22 Supra para 12.

23 Criminal Appeal No. 177 of 2006.
} 
after that of Uganda. Hon Edward Onwong'a of the Republican Liberty Party introduced the Anti-Homosexuality Bill of 2014 (Duffy 2014). In the words of Hon Onwonga'a:

...the Bill aims at providing a comprehensive and enhanced legislation to protect the cherishes culture of Kenyans' legal, religious and traditional family values against the attempts of sexual rights activists seeking to impose their values of sexual promiscuity on Kenyans. ${ }^{24}$

The Bill proposed a punishment of life imprisonment for any Kenyan convicted of the offence of sodomy and a punishment of stoning to death in public for a convicted foreigner in the country. ${ }^{25}$ A punishment of stoning to death is provided as a penalty for anyone found guilty of the offence of aggravated homosexuality, that is, committing same-sex sexual acts: with a person under the age of 18 years; while living with HIV; is in authority over the other person; as a serial offender; with a person with disability. ${ }^{26}$ The Bill was rejected by the Parliamentary Justice and Legal Affairs Committee on the basis that it was unconstitutional and breached international human rights obligations (Duffy 2014). Be that as it may, the thought of introducing a draconian legislation to deal with homosexuality in Kenya shows how religion influences the opinion of political leaders in the country.

The unfavourable disposition of religious leaders towards same-sex sexuality in Kenya is in tandem with the provisions of the current Kenyan Penal Code (Mbote et al. 2018). It is also noteworthy that the Penal Code 'conflates same-sex sexuality with paedophilia and bestiality' (Mbote et al. 2018: 4) and even more striking is the fact that politicians in Kenya show support for anti-sodomy laws in order to win electoral votes (Nyanzi and Karamagi 2015).

\section{The Criminalisation of Homosexual Behaviour in Nigeria}

Nigeria maintains a hard stance when it comes to the criminalisation of homosexual activity and homophobia (Adebanjo 2015). Persons who identify as LGBT are regarded as social deviants in Nigeria (Arimoro 2019). A poll conducted by the British Broadcasting Corporation (BBC) in 2015 shows that $87 \%$ of the population of Nigeria oppose gay rights (British Broadcasting Corporation 2015). Unlike the countries discussed above that criminalise homosexuality in their age-long criminal/ penal codes, ${ }^{27}$ Nigeria has recent anti-gay laws (Arimoro 2019). The laws criminalising homosexual behaviour in Nigeria include the Criminal Code, the Penal Code, the various Shari'ah Codes and the Same-Sex Marriage (Prohibition) Act 2013. ${ }^{28}$

\footnotetext{
24 Preamble to the Bill.

25 Section 2(1)(k) of the Bill.

26 Section 3(1) (a-f) of the Bill.

27 Based on colonial laws received from Britain.

28 The Criminal Code applies in the southern states of the country while the Penal Code applies in the northern states of the country including the federal capital territory, Abuja.
} 
Again, very much like Ghana and Kenya above, religion contributes to the discrimination against same-sex relationships in Nigeria. Rev Musa Asake, a former general secretary of the Christian Association of Nigeria, supported the criminalisation of same-sex relationships when he stated as follows: 'We don't have to drift into a situation where we don't have moral values because someone is giving us money' (Nzwili 2014: para 3). Nigerian Anglican bishops are very vocal when it comes to matters regarding sexuality. They have threatened to break away from the worldwide Anglican Communion over what they consider the compromise of the Church of England regarding recognition of gay clergy (Dickson 2014). Rev Rumo James, a Baptist pastor based in Jos, Nigeria told a reporter that 'homosexualism (sic) is a virus that degrades the family and its values, corrupts human cohabitation and offends God' (Dickson 2014: para 35). A Muslim cleric, Sheik Sani Yahaya who is the national chairman of the Ulama Council of the Jama'atu Izaltil Bid'ah Wa'Ikamatis Sunnah (JIBWIS) on his part has condemned homosexuality using the following words: 'It is an abomination, it is a crime' (Dickson 2014: para 35).

Even before the passing into law of the Same-Sex Marriage (Prohibition) Act 2013 and the Shari'ah codes in 12 northern states, Nigeria has a history of criminalising homosexuality. It appears that the 2013 Act is a response to pressures from the international community to decriminalise homosexuality. Again, those who justify the 2013 Act argue that it addresses the bigger issue of same-sex marriage in addition to criminalising homosexuality (Adebanjo 2015). It is noteworthy that the Act of 2013 has nationwide applicability, unlike the other anti-gay laws which are regional in application. The Criminal Code applies only in the south of the country, the Penal Code applies only in the northern part, while the various Shari'ah codes are state laws that only apply in the respective 12 northern states that have implemented Shari'ah law.

The relevant provisions of the Criminal Code that criminalise same-sex sexual conduct are sections 214, 215 and 217. The offences are captioned as offences against morality. Section 214 of the Criminal Code prohibits 'carnal knowledge against the order of nature' and prescribes a 14-year term of imprisonment for anyone convicted of the offence. An attempt to commit the offence attracts a penalty of seven year's imprisonment. ${ }^{29}$ For procuring another male for same-sex activities or attempting to do so attracts a term of 3 years imprisonment upon conviction. ${ }^{30}$

The Penal Code which applies in the northern part of the country prescribes weightier penalties (Adebanjo 2015). This is not unconnected to the influence of Islamic law on the Penal Code given that it applies in mainly Muslim dominated areas. The offence of 'carnal knowledge against the order of nature' is punishable with a penalty of a 14-year jail term. ${ }^{31}$ Again, under section $405(2)(\mathrm{e})$ of the Penal Code, a male cross-dresser or one who practices sodomy as a profession is a 'vagabond' and may, on conviction be sentenced to imprisonment for a term of up to two years imprisonment or fine or both. ${ }^{32}$

\footnotetext{
29 Section 215 Nigerian Criminal Code.

30 Section 217 Nigerian Criminal Code.

31 Section 284 Nigerian Penal Code.

32 Section 407 Nigerian Penal Code.
} 
With the introduction of Shar'iah in 12 northern states of Nigeria, Muslims who are alleged to have engaged in sodomy may be tried in Shari'ah courts. The 12 different states that have adopted Islamic criminal law have different codes that are not uniform in the prescription and punishment of the offences. For example, Kano (section 129) and Zamfara (section 131) consider the marital status of the accused person when prescribing punishments. An unmarried offender is liable to receive 100 lashes of the cane and a term of one-year imprisonment. For married offenders, the punishment is death by stoning. In Kebbi, all offenders on conviction are to be sentenced to death by stoning. ${ }^{33}$ Bauchi prescribes the death penalty but leaves room for a reprieve by the addition of the phrase 'or any other means decided by the state. ${ }^{34}$ Lesbianism is also categorically proscribed under the various Shari'ah codes. ${ }^{35}$

The more recent 2013 Act is directed at the proscription of same-sex marriages, same-sex relationships, and same-sex relationship associations. Section 1 of the Act prohibits marriage contracts or civil unions between persons of same sex in Nigeria, irrespective of where the marriage is contracted. By implication, the law will affect Nigerians or foreigners who have gay partners or spouses. Again, under the law, only the union between a man and a woman is recognised in Nigeria. ${ }^{36}$

The penalty for contracting gay marriages in Nigeria upon conviction is a jail term of 14 years. ${ }^{37}$ The direct or indirect public show of affection by people in a same-sex relationship, formation of 'gay clubs, associations or organisations' is an offence under the Act. ${ }^{38}$ Furthermore, anyone who officiates, witnesses or supports same-sex marriages or gay societies commits an offence punishable by a ten-year jail term. ${ }^{39}$ Apart from decriminalising same-sex relationships, the law seems to discourage any association with anyone who identifies as gay. It is argued that it is the intent of the draftsman of the law to encourage homophobia (Adebanjo 2015).

\section{The Criminalisation of Homosexual Behaviour in Uganda}

Like the other countries discussed above, the view that homosexuality is foreign and un-African is widespread in Uganda (Jjuuko 2013). In 2010, a Ugandan tabloid (Rolling Stone) published the names, addresses and photographs of alleged homosexuals under the banner 'Hang Them' (Carrington 2014). This led to the killing of several alleged homosexuals including David Kato, a Ugandan gay-rights activist who was bludgeoned to death in his home in 2011 (Carrington 2014). Unlike the other countries discussed so far, homosexuality is even unconstitutional in Uganda. Article 31(2) of the Constitution of Uganda outlaws same-sex marriages.

\footnotetext{
33 Section 132 Kebbi Sharia Code.

34 Section 134 Bauchi Sharia Code.

35 For example, Zamfara (Sect. 135).

36 Sections 3 and 7 Same Sex Marriage (Prohibition) Act 2013.

37 Section 5(1) Same Sex Marriage (Prohibition) Act 2013.

38 Section 4(1) Same Sex Marriage (Prohibition) Act 2013.

39 Section 5(2) and (3) Same Sex Marriage (Prohibition) Act 2013.
} 
Christian Churches have played a significant role in the debate regarding homosexuality in Africa and Uganda in particular (Alava 2016). It is argued that the close link formed between colonial and the missionary project in the country has been carried over to the political system of present-day Uganda (Alava 2016). The Anglican and Catholic church in Uganda have been very much involved in debates regarding the decriminalisation of homosexuality (Ward 2014). It is noted that in sermons in the churches in Uganda, 'homosexuality' is considered as one of the societal ills that the people need to purge themselves from (Ward 2014).

Before the passing into law of Uganda's current law, sodomy laws were 'imported' into Uganda by the British during the era of colonial rule. The British adopted the Penal Code for Uganda on 15 June 1950 which was modelled after the Indian Penal Code and the Australian Penal Code (Ward 2014). Like other similar penal codes already discussed, homosexuality is criminalised under the heading of 'carnal knowledge against the order of nature. ${ }^{40}$ The offence of 'unnatural offences' under which homosexuality falls, is punishable by a term of life imprisonment. ${ }^{41}$ Attempted sodomy is punishable by a term of up to seven years upon conviction of an accused person. ${ }^{42}$

Like Nigeria, Uganda has a more recent anti-gay law. Hon David Bahati, a member of the Ugandan Parliament introduced the Anti-Homosexuality Bill in Parliament (Jjuuko 2013). The Bill aimed to create an offence called homosexuality. ${ }^{43}$ The offence attracts a punishment of a jail term for life. ${ }^{44}$ Aggravated homosexuality under the Bill is punishable by the death penalty. ${ }^{45}$ The Bill provided for the extraterritorial jurisdictional powers to prosecute Ugandans commit the a homosexual offence in the diaspora and powers to extradite offenders back to Uganda for prosecution. ${ }^{46}$ The Bill was signed into law by President Yoweri Museveni on 24th February 2014 after undergoing several amendments (British Broadcasting Corporation 2014). It is noteworthy that President Museveni stated that homosexuality is a personal choice when he signed the bill into law (Cowell 2014). David Bahati, the sponsor of the Bill had also stated that homosexuality can be 'learned and unlearned' and 'a bad behaviour that should not be allowed in our society' (British Broadcasting Corporation 2014). This contrasts with arguments in support that sexual orientation is not a matter of choice but one that is innate with every human being (Arimoro 2018).

\footnotetext{
40 Section 145 of the Uganda Penal Code.

41 Section 145 of the Uganda Penal Code.

42 Section 146 and 148 Uganda Penal Code.

43 Defined as the penetration of the anus or mouth with a penis or any sexual contraption or the use of any object to penetrate or stimulate the sexual organ of a person of the same sex or the touching of another person with the intention of committing the act of homosexuality.

44 Section 2(2) of the Bill.

45 Section 2(2) of the Bill.

46 Sections 16 and 17 of the Bill.
} 


\section{To Decriminalise or Not to Decriminalise}

Should countries where consensual same-sex activity among adults is a crime, decriminalise such behaviour? In the article, it has been argued that received English law and the Abrahamic faiths are the chief reasons for the anti-sodomy laws in Commonwealth African States. Studies show that the early history of England incorporated the offence of 'sodomy' in the common law in defence of Christian values (Kirby 2013). The anti-Sodomy laws which were applicable in Britain during the colonial era were imposed or adopted in the 'huge domain of the British Empire...' (Kirby 2013: 63). In the four states studied, it has been noted that in the description of the offences, similar language is used. This is not unconnected to fact that the penal codes were borrowed from other British colonies. Some very vague terms like 'carnal knowledge' derived from archaic English are still maintained in the penal codes of the countries studied. It is therefore no surprise that Kenya, Uganda and Nigeria have sought to clarify the law by introducing new legislation. Presently, different terminologies have been used to describe the offences. For example, in Nigeria the term marriage is introduced whilst Kenya and Uganda have introduced penalties which have been considered not proportionate to the offences created under new anti-sodomy laws.

It is interesting to note that anti-sodomy laws in the countries discussed in most cases do not proscribe gender transition or cross-dressing, the worrying trend is that the introduction of anti-sodomy laws promotes homophobia and the persecution of the LGBT community. For example, whilst Nigeria's anti-gay marriage law prohibits same-sex marriage, it does not make mention of transgender persons.

Given the fact that these countries proclaim to be secular states, the need to argue for the decriminalisation of sexual activity among persons of the same gender in private on that basis must be championed to make a case for sexual minorities in those countries. Again, given that Britain from where these laws were imported has moved on to decriminalise same-sex sexual conduct, Commonwealth African States should also consider doing same.

The argument that homosexual conduct is foreign or 'unnatural' or 'uncultural' can be challenged by reference to studies that show that homosexuality is not foreign to Africa and has been there before colonial times. Again, people do not just choose to be homosexuals. It is not something anyone wants to be for a period or would like to change after a while. The Commonwealth as a body can begin by encouraging research in this area and sensitisation of communities in Commonwealth States.

Reform should be pursued in the light that consensual sexual activity among persons of the same gender in private is not harmful to the society. In line with the harm theory, what should be considered a crime or treated as such, should be what is detrimental to the society. 


\section{Conclusion}

From the discussion above, studies have shown that the two prevalent factors that account for the continued criminalisation of same-sex sexual activity in Commonwealth Africa are religion and British colonial legislation. Whilst Britain from where Christianity and colonial laws were imported to Africa have repealed her antigay laws, most of the Commonwealth African states refuse to budge and would not succumb to pressure.

In some of the states like Ghana and Kenya, homosexuality is punishable under the head of unnatural carnal knowledge which groups homosexuality as the same with wrongs like bestiality. This grouping helps to fuel the flames of homophobia. The idea that homosexuality is learned and can be unlearned, suggests that the state in these countries adopt a paternalistic approach to the homosexuality debate.

Considering that all the countries studied proclaim to separate religion from the state, it is only fair that when it comes to sexual minorities and the criminalisation of consensual sexual activity amongst adults of the same gender, the state must adopt the harm principle. As rightly pointed out above, only harm provides a suitably nonpartisan base for justifiable legal interference. Again, if the sexual activity of two consenting adults in private does not cause other citizens harm, there should be no justification for making such a behaviour a crime.

Nigeria and Uganda have passed recent laws that clearly define the crime of homosexuality. These two countries, in the face of global pressure, have adopted the politics of religion to sway the support of the majority opinion.

The Commonwealth as a body must adopt a more robust approach towards encouraging the decriminalisation of homosexuality amongst the Member States. The call by former British Prime Minister, Mrs Theresa May to African Heads of States in the Commonwealth to reconsider their laws against homosexuality is in the right direction. This is so because criminal law should focus on barring harm from society and not what happens in private between two adults, in so far as it does not involve violent conduct. Respect for the rights of the minorities should be the focal point of discussions and the policy of the body if Britain is truly sorry for promoting colonial laws that are responsible for the gross violation of the rights of the sexual minorities in the Commonwealth.

Acknowledgements The author is grateful to the two anonymous reviewers for their suggestions and to Dr Uzuazo Etemire and Mr Ntayi Bandawa for proofreading the draft.

Open Access This article is licensed under a Creative Commons Attribution 4.0 International License, which permits use, sharing, adaptation, distribution and reproduction in any medium or format, as long as you give appropriate credit to the original author(s) and the source, provide a link to the Creative Commons licence, and indicate if changes were made. The images or other third party material in this article are included in the article's Creative Commons licence, unless indicated otherwise in a credit line to the material. If material is not included in the article's Creative Commons licence and your intended use is not permitted by statutory regulation or exceeds the permitted use, you will need to obtain permission directly from the copyright holder. To view a copy of this licence, visit http://creativecommons.org/licen ses/by/4.0/. 


\section{References}

Adebanjo, A.T. 2015. Culture, morality and the law: Nigeria's anti gay law in perspective. International Journal of Discrimination and the Law 15(4): 256-270.

Agbiji, O.M., and I. Swart. 2015. Religion and social transformation in Africa: A critical and appreciative perspective. Scriptura 114: 1-20.

Alava, H. 2016. Homosexuality, the holy family and a failed mass wedding in catholic Northern Uganda. Cultural African Studies 9(1): 32-51.

Arimoro, A.E. 2018. When love is a crime: Is the criminalisation of same sex relations in Nigeria a protection of Nigerian culture. Liverpool Law Review 39: 221-238.

Arimoro, A.E. 2019. The criminalisation of consensual same-sex sexual conduct in NIgeria: A critique. Journal of Human Rights and Social Work 4: 257-266.

Arimoro, A.E. 2020. Crime or human right? The criminalization of same-sex relationship conundrum in Nigeria. In Understanding gender in the African context, ed. J. Kurebwa, 142-167. IGI Global.

Atuguba, R.A. 2019. Homosexuality in Ghana: Morality, law, human rights. Journal of Politics and Law 12(4): 113-126.

British Broadcasting Corporation. 2014. Uganda President Yoweri Museveni Signs Anti Gay Bill [Online]. https://www.bbc.co.uk/news/world-africa-26320102. Accessed 6 Dec 2020.

British Broadcasting Corporation. 2015. Nigeria poll suggests $87 \%$ oppose gay rights. https://www.bbc. co.uk/news/world-africa-33325899. Accessed 8 Dec 2020.

British Broadcasting Corporation. 2018. Theresa may “deeply regrets" UK's colonial anti-gay laws [Online]. https://www.bbc.co.uk/news/world-africa-43795440. Accessed 4 Dec 2020.

Carrington, D. 2014. On homosexuality: Uganda's religious leaders. http://edition.cnn.com/2014/10/16/ world/africa/on-homosexuality-ugandas-religious-leaders/index.html. Accessed 8 Dec 2020.

Case, S., et al. 2017. Criminology, 1st ed. Oxford: Oxford University Press.

Cowell, A. 2014. Uganda's president signs antigay bill. New York Times, 24 February.

Dickson, P.C. 2014. Homophobia unites muslims and christians in Nigeria. Global Post, 13 February.

Dripps, D.A. 2010. The liberal critique of the harm principle. Criminal Justice Ethics 17(2): 3-18.

Duffy, N. 2014. Kenya: New stone the gays law proposed by the MPs. Pink News, November.

Embley, J., P. Goodchild, C. Shephard, and S. Slorach. 2020. Legal systems and skills: Learn, develop, apply, 4th ed. Oxford: Oxford University Press.

Eser, A. 1966. The principle of "harm" in the concept of crime: A comparative analysis of criminally protected legal interests. Duquesne University Law Review 4: 345-417.

Feinberg, J. 1987. The moral limits of the criminal law: Harm to others. Oxford: Oxford University Press.

Feinberg, J. 1989. The moral limits of the criminal law: Harm to self. Oxford: Oxford University Press.

Finerty, C. 2012. Being gay in Kenya: The implications of Kenya's new constitution for its Sodomy laws. Cornell International Law Journal 45: 432-459.

Gerber, P. 2014. Living a life of crime: The ongoing criminalisation of homosexuality within the commonwealth. Alternative Law Journal 39(2): 78.

Gnuse, R.K. 2015. Seven gay texts: Biblical passages used to condemn homosexuality. Biblical Theology Bulletin: Journal of Bible and Culture 45(2): 68-87.

Gyasi-Gyamerah, A.A., Amissah, C.M., and Danquah, S.A. 2019. Changing attitudes toward homosexuality in Ghana: The power of attributional discourse. SAGE Open.

Hermalin, B.E. 2005. What is crime? Journal of Institutional and Theoretical Economics 161(2): 303-318.

Human Dignity Trust. 2020. Ghana [Online]. https://www.humandignitytrust.org/country-profile/ghana/. Accessed 6 Dec 2020.

Ireland, P.R. 2013. A macro-level analysis of the scope, causes, and consequences of homophobia in Africa. African Studies Review 56(2): 47-66.

Jjuuko, A. 2013. The incremental approach: Uganda's struggle for the decriminalization of homosexuality. In Human rights, sexual orientation and gender identity in the commonwealth: Struggles for decriminalisation and change, ed. C. Lennox and M. Waites, 381-408. London: Institute of Commonwealth Studies.

Kirby, M. 2013. The Sodomy offence: England's least lovely criminal law export? In Human rights, sexual orientation and gender indentity in the commonwealth: Struggles for decriminalisation and change, ed. C. Lennox and M. Waites, 61-82. London: Institute of Commonwealth Studies.

Kleinig, J. 1978. Crime and the concept of harm. American Philosophical Quarterly 15(1): 27-36. 
Kleinig, J. 2016. The paternalistic principle. Criminal Law and Philosophy 10: 315-327.

Legal Services Commission. 2020. What is crime? [Online]. https://lawhandbook.sa.gov.au/ch12s01.php. Accessed 4 Dec 2020.

Liquin, E.G., S.E. Metz, and T. Lombrozo. 2020. Science demands explanation, religion tolerates mystery. Cognition 204: 104398.

Loveless, J., M. Allen, and C. Derry. 2020. Complete criminal law, 7th ed. Oxford: Oxford University Press.

Mbote, D.K., T.G. Sandfort, E. Waweru, and A. Zapfei. 2018. Kenya Religious leaders' views on same sex sexuality and gender nonconformity: Religious freedom versus constitutional rights. The Journal of Sex Research 55(4-5): 630-641.

McCutcheon, J.P. 2002-2003. Morality and criminal law: Reflections on hart-devlin. Criminal Law Quarterly 47: 15.

Michalowski, R.J. 2016. What is crime? Critical Criminology 24: 181-199.

Mill, J.S. 2008. On liberty and other essays. Oxford: Oxford University Press.

Misra, G. 2009. Decriminalizing homosexuality in India. Reproductive Health Matters 17: 21.

Monaghan, N. 2018. Criminal law, 5th ed. Oxford: Oxford University Press.

Moon, J.W., J.A. Krems, and A.B. Cohen. 2019. Is nothing sacred? Religion, sex and reproductive startegies. Current Directions in Psychological Science 28(4): 361-365.

Mutua, M. 2011. Sexual orientation and human rights: Putting homophobia on trial. In African sexualities, ed. S. Tamale, 452. Fahamu.

Norman, I.D., et al. 2016. Homosexuality in ghana. Advances in Applied Sociology 6(1): 12-27.

Nyanzi, S., and A. Karamagi. 2015. The social-political dynamics of anti-homosexual legislation in Uganda. Agenda 29(1): 24-38.

Nzwili, F. 2014. Nigeria's religious leaders welcome controversial anti-gay law. Washington Post, 16 January.

Okeke, C.O., Ibenwa, C.N., and Okeke, G.T. 2017. Conflicts between African traditional religion and christianity in Eastern Nigeria: The Igbo Example. SAGE Open 1-10.

Oliveira, J.M. 2012. Harm and offence in mills conception of liberty. Oxford: Oxford University Press.

Oloka-Onyango, J. 2015. Debating love, human rights and identity politics in East Africa: The case of Uganda and Kenya. African Human Rights Law Journal 15: 28-57.

Omelicheva, M.A. 2018. Religion and politics: Examining the impact of faith on political participation. Religion, State and Society 46(1): 4-25.

Refugee Review Tribunal. 2007. RRT research response [Online]. https://www.justice.gov/sites/default/ files/eoir/legacy/2014/09/25/homosexuals-legal\%20provisions.pdf. Accessed 20 Dec 2020.

Salau, M.B. 2020. Religion and politics in Africa. Journal of Law and Religion 35(1): 165-177.

Saunders, B. 2013. Reformulating mill's harm principle [Online]. https://dspace.stir.ac.uk/handle/1893/ 18198\#.X8-E42j7Q2w. Accessed 5 Dec 2020.

Spencer, K., and Mohr, J.W. 2019. Crime [Online]. https://search.proquest.com/docview/2316655701? accountid=14693\&rfr_id=info\%3Axri\%2Fsid\%3Aprimo. Accessed 4 Dec 2020.

Stewart, H. 2010. The limits of the principle of harm. Criminal Law and Philosophy 4: 17-35.

The Global Alliance for LGBT Education. 2020. Homosexuality and transgenderism in the quaran [Online]. https://www.gale.info/en/database/reading/homosexuality-and-transgenderism-in-thequran. Accessed 6 Dec 2020.

Tur, R. 1985. Paternalism and criminal law. Journal of Applied Philosophy 2(2): 173-189.

Ward, K. 2014. The role of the Naglican and Catholic Churches in Uganda in public discourse on homosexuality and ethics. Journal of Eastern African Studies 9(1): 127-144.

Publisher's Note Springer Nature remains neutral with regard to jurisdictional claims in published maps and institutional affiliations. 